\title{
The Importance of the Sustainability of the Expanded Programme on Immunization and the Maintenance of Vaccination Rates During the COVID-19 Outbreak
}

\author{
Gökmen Özceylan* \\ Specialist in family medicine, Republic of Turkey Ministry of Health, Reşadiye Family Medicine Center, Turkey
}

Submission: September 18, 2020; Published: September 21, 2020

*Corresponding author: Gökmen Özceylan, Specialist in family medicine, Republic of Turkey Ministry of Health, Reşadiye Family Medicine Center, Turkey

\section{Introduction}

Vaccines are one of the most important discoveries of world science for the welfare of humanity in the last century. According to the statements of the World Health Organization (WHO), the two health practices that have the greatest contribution to health worldwide are vaccination and use of clean water [1]. WHO recommended to all countries the implementation of the Expanded Programme on Immunization (EPI) in 1974 to protect the health of their citizens as well as people all over the world [2]. Today, almost every country's national vaccination system is integrated into their health systems. Every country has now accepted the following truth: The cost of vaccines for countries are much less than the cost of diseases that vaccines protect from.

Regarding vaccines, the data for the year 2017 in the reports published the WHO's Strategic Advisory Group for the achievement of global vaccination goals are very important. Because these data show that the highest vaccination rates ever reported have been achieved in the world [3]. However, according to the WHO data for 2018, massive measles, diphtheria and polio virus outbreaks have been reported, which resulted in deaths in many parts of the world. For example, according to the 2017 data of the European Centre for Disease Prevention and Control (ECDC), the number of measles in Europe was approximately three times of 2016, and $87 \%$ of diagnosed cases refused to be vaccinated. The deaths of 35 patients were reported in this measles outbreak in Europe due to vaccination refusals [4]. Vaccine refuse and hesitancy movements that have occurred in some countries after this period have had a significant impact on the decrease of vaccination rates. The health systems of countries all over the world have thus faced a new problem that may affect vaccination rates, ushering in a period when countries have to plan their discussions and studies according to this new trend, use social media, internet and other mass media to contend with anti-vaccine advocates more actively and explain the importance of vaccines to their communities [5].

The COVID-19 pandemic, which started in January 2020 in the Wuhan province of China and was declared as a pandemic by WHO on March 11, 2020, has infected approximately 8 million people up to mid-June 2020 and has caused the death of over 400 thousand people [6]. WHO, in his assessment of the epidemic, expressed concerns that the pandemic has been increasing its influence day by day and that the peak numbers have still not been reached in the world as of June 15 [7]. This pandemic has severely damaged health systems in many countries and has even paralyzed them in some countries. Leaving aside the political debates on WHO, it seems very difficult for health systems in countries with low socioeconomic development levels to emerge from such an influential epidemic without collapse. This possibility brings forth a risk that is not to be underestimated. Any health system that can collapse will reduce the vaccination rates of that country, and even if we find ways out of this epidemic over time, millions of new babies who cannot be properly vaccinated may trigger new outbreaks of well-known virulent or disabling diseases.

It is a fact that in this world order, where globalization enables easier transportation and removes economic barriers, the countries that can maintain their own vaccination rates will also be open to new infections due to unlimited transportation ability, economic mobility and uncontrolled migration movements and will have difficulty in protecting their society's health. Scientists from all over the world need to see this fact without delay and, 
while struggling with the COVID-19 outbreak on the one hand, they should strengthen their country's vaccination programs on the other hand, and, even if they cannot raise the vaccination rates, they should at least target the 2017 data and commit to joint immunization efforts. Many important scientific studies are conducted, and meetings and conferences are organized on how to overcome this problem and protect from new outbreaks [8]. Each country is looking for ways to combat through different practices within its own health system.

The health system of each country in the world plans its mechanism based on its own circumstances and social ethic rules. However, in this pandemic process, insufficient vaccination that may occur in underdeveloped countries with fragile health systems may put all countries of the world at risk. In particular, countries with high socioeconomic development rates should support these underdeveloped and fragile health systems by contributing to central vaccine support programs that can be created in order to reattain the 2017 vaccine rates. Because, in an era where population mobility has become so easy, we all can see how quickly an epidemic can spread to developed countries from a country like China that is assumed to be far away. This is a task not to be postponed or neglected.

Countries of the world should establish a common vaccination monitoring board without delay and every country should be able to monitor current vaccination rates the way they announce
COVID-19 total numbers. Health ministries of each country should share such data transparently with the board and any deficiency should be compensated without delay. These data should be open in a transparent way for the use of scientists and relevant scientific studies should be encouraged. Such an undertaking will not only reveal the magnitude of the problem and enable us to analyze the risks correctly, but also allow us to find swift and cost-effective solutions in formulating measures.

\section{References}

1. WHO (2000) World Health Report 2000: Health Systems-Improving Performance. Geneva, Switzerland.

2. https://www.who.int/immunization/programmes_systems/supply_ chain/benefits_of_immunization/en/

3. WHO (2017) Global Invasive Bacterial Vaccine-Preventable Disease and Rotavirus and Pediatric Diarrhea Surveillance Networks Bulletin.

4. https://www.ecdc.europa.eu/en/publications-data/measles-andrubella-monitoring-january-2017

5. Dubé E, Gagnon D, MacDonald N, Bocquier A, Peretti-Watel P, et al. (2018) Underlying factors impacting vaccine hesitancy in high income countries: a review of qualitative studies. Expert Rev Vaccines 17(11): 989-1004.

6. https://www.worldometers.info/coronavirus/

7. https://www.who.int/health-topics/coronavirus\#tab=tab_1

8. https://www.cdc.gov/vaccines/events/nic/index.html

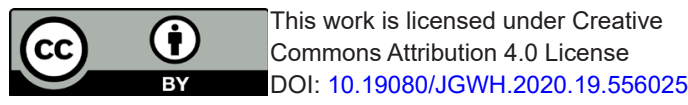

\section{Your next submission with Juniper Publishers will reach you the below assets}

- Quality Editorial service

- Swift Peer Review

- Reprints availability

- E-prints Service

- Manuscript Podcast for convenient understanding

- Global attainment for your research

- Manuscript accessibility in different formats

( Pdf, E-pub, Full Tsext, Audio)

- Unceasing customer service

Track the below URL for one-step submission https://juniperpublishers.com/online-submission.php 